\title{
Populism and Extremism: The Immediate Political Challenges to Europeanism
}

\author{
Shaen Corbet $^{a *}$, Charles Larkin ${ }^{b}$, \\ ${ }^{a}$ DCU Business School, Dublin City University, Dublin 9 \\ ${ }^{b}$ Trinity Business School, Trinity College Dublin, Dublin 2 \\ *Corresponding Author: shaen.corbet@dcu.ie
}

\begin{abstract}
In the midst of the banking and economic crises that evolved most aggressively within the peripheral European states, the European Central Bank proceeded to overcome their rigid approach to monetary policy as the Eurozone edged closer towards economic collapse. The financial crises have now been closely followed by a political crisis inspired by the dramatic influx of illegal immigration. As a result, Europe finds itself at a crossroads inspired by political spectrum shifts to the left and the right, with fear, uncertainty fuelling nationalist revolt across a host of European nations. We must briefly consider explanations for the individual political spectral-shifts within the European Union, while outlining the growth of populist movements since the most recent parliamentary elections.
\end{abstract}

Keywords: Populism; Anti-austerity; European Union; Financial Crisis; Migration; Integration. 


\section{Introduction}

Responding to the European economic crisis required change within the European Union. To satisfy the needs of twenty-eight exceptionally different member states, the simplistic 'one-size-fits-all' approach may no longer be the most efficient solution, particularly as there are exceptional differences to the challenges that each member state faces. The slow moving Brussels administration and the Post-war consensus at the centre of the European project appears to be unable to characterise and solve the multitude of differing issues it faces. The recent rise of populist and extremist movements can in part be explained as a response to the 2007 financial crisis. In this paper we use a bespoke database to illustrate the shift in the political spectrum across Europe over the past decade. In this age of social media-driven mistruths, dis-truths and alternative-truths, the speed of political spectrum change appears to have overcome the structure it was designed to be contained.

A loss of identity is one potential rationale behind such acute European-level inaction. A lack of leadership is another. We identify the stress of financial crises and exceptional levels of immigration as key drivers that have caused each European member-state to enter a period of inward reflection. The Brexit response, whether driven by renewed xenophobia and nationalism or can we simply attribute such reaction to the desperation with respect to the status quo?

Our aim in this article is to offer a brief yet comprehensive overview of the changing political spectrum in the European Union in an attempt to identify the conceptual challenges contained within the current populist dislocations to the leftwing and right-wing. The combination of economic and political crises weighed heavily on the concept of European Union, therefore we attempt to problematize the political loop that we have found ourselves in, namely that European politics has shaped our non-response to our current problems, and that these problems are now shaping European politics. One must ask how established democracies can falter within such political decision-making, however the crises and problems within Europe of the 2000's have been exceptionally extraordinary. Populist parties now further attempt to generate the catalyst for nationalist change within the midst of potential catastrophe.

\section{The growth of the populist movement in Europe}

Populism is defined as the generation of political ideas and activities that are intended to generate the support of ordinary people by giving them what they want. Further, 'given the high levels of inequality in many of these societies, political platforms built on redistribution are not surprising. But populist rhetoric and policies 
are frequently to the left of the median voter's preferences, and such policies may arguably harm rather than help the majority of the population' (Acemoglu et al. [2013]).

During the recent years of crisis and austerity, there has been a significant rise of populist and nationalist parties in Europe, with some winning elections and disturbing previously established hegemonies, causing significant realignments and thus changing the rules of the political game (Rooduijn and Akkerman [2017]). Populism has often been described as the ultimate threat for Europe. The alarming populist challenge that is so often discussed in the public sphere appears to possess solid foundation, as populists of various shapes and colours are indeed gaining ground in Europe and across the world (Wejnert [2014]). This populist surge has brought renewed intensity to the debate around the crisis of democracy itself and the capacity of existing institutions to express and empower citizens, upholding democracy's promise for popular sovereignty.

The left-wing movements of Europe have found success by appealing to those most affected by austerity, with dramatic growth in Greece, Ireland, Portugal and Spain. The most prolific examples are SYRIZA in Greece, Podemos in Spain and the Anti-Austerity Alliance/Solidarity in Ireland. SYRIZA was founded as an alliance of left-wing and radical left-wing parties in 2004 are currently in power in the Greek government, led by Greek Prime Minister Alexis Tsipras. The party has obtained support through the location of a common ground with Greek citizens against the neoliberal reform of the pension and security systems, opposing new anti-terror legislation and reviewing the role of the European Union and Greece's position on it. Podemos was founded in March 2014 in the aftermath of the 15-M Movement ${ }^{1}$ protests against inequality and corruption by Pablo Iglesias. The Anti-Austerity Alliance/Solidarity is an Irish anti-capitalist party launched in 2014, obtaining three seats in the Irish Dail after running forty candidates ${ }^{2}$.

Nationalist parties have also received significant support through a combination

\footnotetext{
${ }^{1}$ The 15-M Movement possesses origins in social networks such as Democracy NOW and began demonstrations on 15 May 2011 close to the local and regional Spanish elections held on 22 May 2011. It has built its policies upon economic recovery with an emphasis on public control, poverty reduction and social dignity via a basic income for everyone. It promotes liberty, equality and fraternity, while redefining sovereignty through the curtailment of the Treaty of Lisbon.

${ }^{2}$ In 2015, it formed an alliance gaining three further seats and renaming itself as Anti-AusterityAlliance-People Before Profit/Solidarity. It seeks a greater socialist voice and a political platform committed to abolishing water charges, the universal social charge for low-middle income earners and other austerity measures implemented in Ireland in the aftermath of the financial crisis (Corbet [2016])
} 
of dissident voices opposing austerity measure and immigration ${ }^{3}$. Nationalistic views have been primarily driven by the harsh austerity measures implemented, however, it has been further influenced by the dramatic increase of illegal immigration (Djajić and Michael [2014]) and perceived loss of European border control and immigration policy (Wright et al. [2016]) which has been the central driving force of support for the far-right which have become more prominent in a range of European countries. Apaydin [2016] found that supranational loyalties do not always discourage individuals from honouring their national political commitments, where member state nationals who are loyal to the EU may not show up at the supranational elections if national institutions are perceived to be more powerful to influence decision-making in Brussels.

The rise of right-wing parties has been correlated with the promotion of populist Euroscepticism combined with continuous anti-immigration commentary and opposition to multi-cultural integration. The terrorist attacks in Europe in 2015 and 2016 directly aided the development of support for these parties, in some cases advocating fascist rhetoric. One example of such ultra-nationalism is witnessed in the growth in support for the Greek party Golden Dawn, who obtained 18 seats out of 300 in the Hellenic parliament despite an ideology of neo-Nazism and fascism ${ }^{4}$. The UK Independence Party was one of the driving forces supporting the decision for the United Kingdom to leave the European Union, openly described as a right-wing populist parties sharing characteristics with the United States Tea Party Movement. It has held British nationalism at its core, obtaining support through hard Euroscepticism and national sovereignty as defined by harsh implementation of policies based on immigration and foreign policy. The People's Party-Our Slovakia share similar characteristics based on extreme anti-Roma policies while obtaining $8 \%$ of the Slovakian vote. Austria's anti-immigration Freedom Party presented Norbert Hofer as a presidential candidate promoting the strengthening of the Austrian border and

\footnotetext{
${ }^{3}$ Nationally, Law and Justice obtained $37.6 \%$ of the popular vote in 2015 in Poland to enter government, while the New Flemish Alliance obtained 20.3\% in Belgium in 2014. The Finns Party obtained $17.7 \%$ in Finland while the National Alliance received $16.6 \%$ in Latvia. Although not entering government, the Freedom Party of Austria received 20.5\% in 2013, Jobbik, 20.2\% in Hungary in 2014 and Sinn Fein 13.8\% in Ireland in 2016. At the regional level, the Scottish National Party and Basque National Party have obtained power in Scotland and Spain respectively. These parties share political ideologies ranging from regionalism, national and social conservatism, left-wing nationalism, republicanism, economic nationalism, Christian democracy and a range of Eurosceptic views

${ }^{4}$ The party have been linked with the use of Nazi symbolism and have represented political rhetoric possessing dangerously similar characteristics to that of the German Nazi party
} 
army, who obtained $49.7 \%$ and losing initially by 30,000 votes, however in a court decided re-count, this winning margin increased to 6\%. The Swedish Democrats party, possessing roots in the white supremacist movement won $13 \%$ of the Swedish vote in September 2014 calling for heavy restrictions upon immigration. The Party for Freedom in The Netherlands operates while proposing Eurosceptic, anti-Islam views, while the Alternative for Germany party which started three years ago won $25 \%$ of the vote in the German state elections in 2016, possessing a policy platform indicating that 'Islam does not belong in Germany' while calling for a ban on the construction of mosques.

\section{The changing spectrum of European populism}

As Table 1 shows, there have been distinctive spectral changes within European politics since the financial crisis began in 2007. Portugal, Ireland, Spain and Greece all experienced significant shifts to the left-wing in the era after the crisis along with Austria. There is clear evidence of the exceptional peak government debt that accumulated through banking crises in each country. This left-wing shift has been driven by the growth of wide-reaching anti-austerity movements. The turmoil in Greece and Austria is further represented by the significant levels of government debt and income inequality, however there are also substantial increases in the number of illegal immigrants entering each country. Italy and Cyprus also experienced substantial economic reversal during the period after 2007, however Cyprus remained centrallyfocused, but Italy shifted to the right-wing. The reported year on year level of illegal immigration increased by 1,013\% in 2015, exacerbating deep-rooted nationalism, but not extremism in a move to centre-right from the centre-left.

\section{Insert Table 1 about here}

There are notable results to discuss within each spectrum of political change. The left-wing in Greece obtained its support as a result of a 37\% collapse in central support. However Spain and Portugal observed the most extreme shifts to the farleft of $18 \%$ and $41 \%$ respectively. Portugal experienced a spectral reversal from the far-right to the left-wing and far-left, a result only matched nominally by the collapse

of the far-left in Poland which transferred to the right-wing. Germany experienced an $8 \%$ move to the left in the most recent elections, however polls predict a shift to the right in the upcoming 2017 elections. Hungary experienced the largest influx of illegal immigrants in 2015, reported to be $11,030 \%$ year-on-year. This is reflected in the spectral shift to the right-wing in the most recent elections. Eastern and 
Southern Europe have experienced the largest influx of illegal immigration in 2015 and with the exception of Greece, these results are beginning to reflect within national parliaments.

\section{Insert Table 2 about here}

In the most recent twenty-eight European member state elections, five countries have experienced spectral shifts to the left, twelve counties to the right and eleven countries have remained centrally positioned. As Table 2 shows, there are clear rationale behind such results. Left-wing populism obtained substantial support through opposition to austerity within the countries contained in the sample. This is represented through the $127 \%$ average peak government percentage debt-toGDP statistic. There is also a significant disparity in income inequality within these countries indicating that not only did the governments within these states oversee substantially adverse recessionary crises, the austerity introduced as a solution led to shifting income comparisons between high- and low-earning citizens. Illegal immigration statistics in left-orientated countries are driven by Greek and Austrian estimates. When removed, the remaining three countries possess an average netemigration statistic of $42 \%$. Right-wing populism has been based primarily on the fear imposed through illegal immigration. Central tendency arguments remain for those European states that have maintained or repositioned to a central political spectrum, as found in the relatively low comparable illegal immigration statistics and average peak political debt.

\section{Immediate challenges to the European Union}

Free speech remains a central right, although we have recently witnessed the inherent dangers contained within social media platforms such as Twitter, Facebook and Instagram to name a few. Engaging in populist behaviour is now far easier than ever before, with readily available, sometimes amateur solutions to complex problems generated by such social media platforms, 160 characters in fact, when utilising the services of Twitter. The dangers inherent within this mechanism of information transfer are enhanced in emotional situations, particularly with the development of information with little or no factual grounding that is simply replicated and redistributed by those who either willingly or maliciously select to do so. This uninformed information, whether driven by innocent comment, emotional attachment or general malicious behaviour now has the potential to reach a global audience rapidly given network effects. It is not uncommon for facts and fiction to become confused or 
unidentifiable along the way. There have been wide-sweeping accusations of targeted manipulation and/or misreporting of facts during recent US election campaign, particularly surrounding the targeted placement of misreported news releases. Notably this has been the focus of the US Government investigation led by former FBI director Robert Muller. We have also witnessed the use of Twitter by the new US President to make explicit and extraordinary remarks which have resulted in a range of outcomes such as stock market movements and protests. Social media appears to have generated a platform in which fiction and fact intertwine. This creates serious democratic accountability concerns as voters unable to generate their own opinions or that simply follow the lead of those they perceive to be either possessing advanced subject-knowledge or authority on key issues.

Social media is changing the nature and foundations of political campaigns. One key issue is the immediate bypassing of journalistic integrity. Social media usage is direct to the user, therefore fixating on the key points of an incident whether positive or negative, while demanding brevity due to the nature of the mediums use. Once more, the use of Twitter removes information transfer through tone and expression, moving politicians towards a world where there is little or no interaction with journalists or the population at large, with releases mostly in a sanitised form to remove questionable material. This potentially has the effect of polarising politics depending on the social media platform used; further those that offer an opinion may not have the space to adequately express so efficiently, or indeed may express it to those who pick and choose that which they want to portray rather than offering information vital to present valid argument.

\section{Should extraordinary democratic results receive a second-chance?}

In an environment of confusion and uncertainty, it is quite simple for mistruths to become 'truths'. It is also quite possible for populist movements to reverse. One recent example of the efficiency of scaremongering and misreporting of facts centred on the Lisbon I referendum held in Ireland in June 2008. Ireland was the only European state to hold a referendum on the Treaty, which was then defeated by $53.4 \%$ to $46.6 \%$, which was largely based upon scaremongering targeting the agricultural sector, broad legislative inaccuracies and widespread accusations of detrimental effects to worker's rights in Ireland. The Irish government were left with no option other than to debate these issues with their European counterparts, to which certain amendments were introduced. Euroscepticism was central to the spread of these 
inaccuracies, primarily through a party named Libertas ${ }^{5}$ representing conservatism and economic liberalism combined with central opposition to the European project. The Irish government defeated the rise of this populistic and fear-distilling group and the Libertas candidates that contested the European Parliamentary elections of June 2009 were heavily defeated. Ireland then voted in favour of this amended Treaty, known as Lisbon II in October 2009, which was passed by $67.1 \%$ to $32.9 \%$.

Does this indicate that the UK should vote for Brexit once again? Support for leaving the EU has fallen dramatically with petitions seeking a second referendum on the decision to leave obtaining substantial support in late 2016 and early 2017. Democracy must prevail no matter what the cost, however the multitude of political and economic risk surrounding the role that both Scotland and Northern Ireland will have in the future appears to be generating the most uncertainty. Support for a second Scottish independence referendum has excelled, which appears to be inspiring the use of the option for a border-poll in Northern Ireland. Should each country obtain independence from the UK, there would be both logic and support within European circles for both to obtain European single-market entry, with Northern Ireland potentially entering Europe through unification with Ireland. The UK in its new-found state would therefore be isolated and fully reliant on the trade deals that they can generate in the two-year period after triggering Article 50.

In an anti-Brexit speech in February 2017, ex-Prime Minister Tony Blair stated: 'I want to be explicit. Yes, the British people voted to leave Europe. And I agree that the will of the people should prevail. I accept right now there is no widespread appetite to re-think. But the people voted without knowledge of the terms of Brexit. As these terms become clear, it is their right to change their mind. Our mission is to persuade them to do so'. He further accused 'Brexiteers' of 'insulting the intelligence of the British people to say they got it wrong' in a resilient and charismatic tone. However, observations from outside the UK would simply state that this speech would have been better represented to the British people in mid-2016.

\section{Conclusion}

Populist movements on both the left-wing and right-wing have existed within Europe before the events that have inspired the UK's decision to leave the European Union. The UK can take credit for being the first country to truly force change in due course, which is vital should the concept of pan-European unity be considered valid

\footnotetext{
${ }^{5}$ Libertas was an Irish political party that contended the European Parliament elections in Ireland under a common banner of Libertas.eu which was established by Declan Ganley.
} 
in the future. It is now completely in the hands of those people that have decided to force change. It is clear from our database that the pressures of the economic crisis and the sudden influx of migration has generated a political response that has pulled political movements away from the centre and towards left and right fringes. This has created a challenge for the post-war order, most clearly in Europe. That said, the European project may be far more resilient than some political anarchists once perceived. 


\section{Bibliography}

Acemoglu, D., G. Egorov, and K. Sonin (2013). A political theory of populism. The Quarterly Journal of Economics 128(2), 771-805.

Apaydin, F. (2016). The supranational dimension of voting in national elections across six european democracies: rethinking albert hirschman's exit, voice and loyalty. European Political Science 15, 73-88.

Corbet, S. (2016). Turning tigers into piigs: The role of leverage in the irish economic collapse. In Lessons from the Great Recession: At the Crossroads of Sustainability and Recovery, pp. 21-55. Emerald Group Publishing Limited.

Djajić, S. and M. S. Michael (2014). Controlling illegal immigration: on the scope for cooperation with a transit country. Review of International Economics 22(4), 808-824.

Rooduijn, M. and T. Akkerman (2017). Flank attacks: Populism and left-right radicalism in western europe. Party Politics 23(3), 193-204.

Wejnert, B. (2014). Populism and democracy: Not the same but interconnected. In The many faces of populism: Current perspectives, pp. 143-161. Emerald Group Publishing Limited.

Wright, M., M. Levy, and J. Citrin (2016). Public attitudes toward immigration policy across the legal/illegal divide: The role of categorical and attribute-based decision-making. Political Behavior 38(1), 229-253. 
Table 1: Changing European Government Spectrum since the 2007 financial crisis

\begin{tabular}{|c|c|c|c|c|c|c|c|c|c|c|}
\hline Country & FL & LW & Cent & RW & FR & $\begin{array}{c}\text { Current } \\
\text { Spectrum }\end{array}$ & $\Delta^{1}$ & $\begin{array}{l}\text { Reported } \Delta \% \\
\text { ill. Immig. }{ }^{2}\end{array}$ & $\begin{array}{c}\text { Income } \\
\text { Inequality }\end{array}$ & $\begin{array}{l}\text { Peak gov. } \\
\text { Debt }^{4}\end{array}$ \\
\hline \multicolumn{11}{|c|}{ Spectrum change to the left } \\
\hline Greece & $3 \%$ & $39 \%$ & $-37 \%$ & $-13 \%$ & $5 \%$ & Centre-Left & $33 \%$ & $626 \%$ & $27 \%$ & $182 \%$ \\
\hline Portugal & $41 \%$ & $11 \%$ & $-19 \%$ & $0 \%$ & $-33 \%$ & Left-Wing & $19 \%$ & $-44 \%$ & $-7 \%$ & $138 \%$ \\
\hline Ireland & $3 \%$ & $13 \%$ & $-27 \%$ & $0 \%$ & $0 \%$ & Centre-Right & $16 \%$ & $-6 \%$ & $-5 \%$ & $132 \%$ \\
\hline Austria & $0 \%$ & $-1 \%$ & $-13 \%$ & $10 \%$ & $0 \%$ & Centre & $10 \%$ & $80 \%$ & $9 \%$ & $85 \%$ \\
\hline Netherlands & $0 \%$ & $-3 \%$ & $-4 \%$ & $8 \%$ & $0 \%$ & Centre-Right & $6 \%$ & $-19 \%$ & $-27 \%$ & $73 \%$ \\
\hline Cyprus & $0 \%$ & $3 \%$ & $-11 \%$ & $3 \%$ & $-1 \%$ & Centre-Right & $5 \%$ & $-49 \%$ & $29 \%$ & $146 \%$ \\
\hline Latvia & $0 \%$ & $0 \%$ & $-6 \%$ & $3 \%$ & $0 \%$ & Centre-Right & $3 \%$ & $75 \%$ & $-5 \%$ & $75 \%$ \\
\hline Malta & $0 \%$ & $-3 \%$ & $1 \%$ & $0 \%$ & $0 \%$ & Centre-Left & $3 \%$ & $-67 \%$ & $-16 \%$ & $181 \%$ \\
\hline Denmark & $-2 \%$ & $8 \%$ & $-1 \%$ & $-8 \%$ & $0 \%$ & Centre & $2 \%$ & $241 \%$ & $17 \%$ & $50 \%$ \\
\hline Belgium & $-1 \%$ & $5 \%$ & $-4 \%$ & $-1 \%$ & $-1 \%$ & Centre-Right & $2 \%$ & $20 \%$ & $-10 \%$ & $8 \%$ \\
\hline \multicolumn{11}{|c|}{ Spectrum change to the Right } \\
\hline Bulgaria & $0 \%$ & $-43 \%$ & $56 \%$ & $0 \%$ & $-13 \%$ & Centre & $58 \%$ & $1,436 \%$ & $5 \%$ & $17 \%$ \\
\hline Estonia & $-56 \%$ & $0 \%$ & $49 \%$ & $7 \%$ & $0 \%$ & Centre-Right & $49 \%$ & $136 \%$ & $-5 \%$ & $1 \%$ \\
\hline Hungary & $-40 \%$ & $-1 \%$ & $43 \%$ & $-6 \%$ & $0 \%$ & Centre-Right & $47 \%$ & $11,030 \%$ & $9 \%$ & $94 \%$ \\
\hline Italy & $-9 \%$ & $-17 \%$ & $14 \%$ & $-7 \%$ & $0 \%$ & Centre-Right & $33 \%$ & $1,013 \%$ & $8 \%$ & $135 \%$ \\
\hline Slovakia & $-8 \%$ & $0 \%$ & $35 \%$ & $-30 \%$ & $9 \%$ & Centre & $29 \%$ & $359 \%$ & $-4 \%$ & $59 \%$ \\
\hline Poland & $-61 \%$ & $-2 \%$ & $26 \%$ & $34 \%$ & $0 \%$ & Centre-Right & $28 \%$ & $183 \%$ & $-16 \%$ & $56 \%$ \\
\hline France & $0 \%$ & $-12 \%$ & $24 \%$ & $-12 \%$ & $0 \%$ & Centre & $25 \%$ & $89 \%$ & $12 \%$ & $89 \%$ \\
\hline Romania & $0 \%$ & $-23 \%$ & $3 \%$ & $0 \%$ & $0 \%$ & Centre & $23 \%$ & $117 \%$ & $18 \%$ & $42 \%$ \\
\hline Czech Republic & $-15 \%$ & $0 \%$ & $12 \%$ & $1 \%$ & $0 \%$ & Centre & $14 \%$ & $165 \%$ & $-8 \%$ & $41 \%$ \\
\hline Sweden & $-1 \%$ & $2 \%$ & $-19 \%$ & $13 \%$ & $0 \%$ & Centre & $14 \%$ & $42 \%$ & $7 \%$ & $43 \%$ \\
\hline Slovenia & $0 \%$ & $1 \%$ & $10 \%$ & $0 \%$ & $-14 \%$ & Centre & $13 \%$ & $358 \%$ & $5 \%$ & $22 \%$ \\
\hline Finland & $0 \%$ & $-12 \%$ & $10 \%$ & $-1 \%$ & $0 \%$ & Centre & $13 \%$ & $332 \%$ & $-2 \%$ & $54 \%$ \\
\hline
\end{tabular}

Note: The above results are based on the most recent election results that have taken place in each European member-state. FL, LW, Cent, RW and FR represent far-left, left-wing, centre, right-wing and far-right respectively. ${ }^{1} \Delta$ represents the change in the number of seat towards the denoted political spectrum. ${ }^{2}$ Data taken from the World Bank Databank based on the reported number of illegal immigrants that entered each European member state in 2015. ${ }^{3}$ Income inequality is based on the change in each European member state between 2006 and 2016 as measured by the proportion of income earned by the bottom $10 \%$ of earners and that of the top $10 \%$ of earners.

${ }^{4}$ Peak government debt is based on the period between 2005 and 2016. 
Table 2: European Government Spectrum change since the 2007 financial crisis

\begin{tabular}{lrrrrrrrrr}
\hline Spectrum & FL & LW & Cent & RW & FR & $\Delta^{\mathbf{1}}$ & $\begin{array}{c}\text { Reported } \Delta \% \\
\text { ill. Immig. }\end{array}$ & $\begin{array}{c}\text { Income } \\
\text { Inequality } 3\end{array}$ & $\begin{array}{c}\text { Peak gov. } \\
\text { Debt }^{4}\end{array}$ \\
\hline Left & $13 \%$ & $13 \%$ & $-26 \%$ & $1 \%$ & $-6 \%$ & 22 & $116 \%$ & $9 \%$ & $127 \%$ \\
Centre & $-1 \%$ & $2 \%$ & $-5 \%$ & $1 \%$ & $0 \%$ & 3 & $73 \%$ & $2 \%$ & $76 \%$ \\
Right & $-16 \%$ & $-7 \%$ & $22 \%$ & $0 \%$ & $-4 \%$ & 29 & $1,272 \%$ & $2 \%$ & $54 \%$ \\
\hline
\end{tabular}

Note: The above results are based on the most recent election results that have taken place in each European member-state. FL, LW, Cent, RW and FR represent far-left, left-wing, centre, right-wing and far-right respectively. ${ }^{1} \Delta$ represents the change in the number of seat towards the denoted political spectrum. ${ }^{2}$ Data taken from the World Bank Databank based on the reported number of illegal immigrants that entered each European member state in 2015. ${ }^{3}$ Income inequality is based on the change in each European member state between 2006 and 2016 as measured by the proportion of income earned by the bottom $10 \%$ of earners and that of the top $10 \%$ of earners.

${ }^{4}$ Peak government debt is based on the period between 2005 and 2016. 